\title{
STUDI KEMAMPUAN SLALOM DRIBBLING DAN LONG PASSING PADA KLUB SEPAKBOLA WANITA DI KOTA BENGKULU
}

\author{
Debi Sintia Putri \\ E-mail : Debisintiaputri@gmail.com \\ Universitas Bengkulu \\ Yarmani \\ Universitas Bengkulu \\ Aliman \\ Universitas Bengkulu
}

\begin{abstract}
ABSTRAK
Penelitian ini bertujuan untuk mengetahui kemampuan slalom dribbling dan long passing pada klub sepakbola wanita di Kota Bengkul. Penelitian ini dilakukan di masing-masing tempat latihan klub sepakbola wanita di Kota Bengkulu. Populasi dalam penelitian ini adalah pemain sepakbola wanita di Kota Bengkulu yang berjumlah 60 orang. Penelitian ini merupakan penelitian deskriptif kuantitatif yang menggunakan metode survei dan teknik pengumpulan datanya menggunakan teknik tes dan pengukuran. Teknik pengambilan sampel menggunakan total sampling, dimana jumlah keseluruhan populasi di jadikan sampel. Instrumen yang di gunakan dalam penelitian ini adalah tes kemampuan slalom dribble dan passing lambung milik danny mielke. Teknik analisis data yang digunakan adalah statistik deskriptif dalam bentuk persentase. Hasil penelitian menunjukkan bahwa kemampuan slalom dribbling pada klub sepakbola wanita di Kota Bengkulu dinyatakan kurang dengan presentase $36,67 \%$, dan kemampuan long passing pada klub sepakbola wanita di Kota Bengkulu dinyatakan sangat kurang dengan presentase $66,67 \%$.
\end{abstract}

Kata Kunci : Kemampuan, Slalom Dribbling, Long Passing, Sepakbola Wanita.

\begin{abstract}
This study aims to determine the ability of slalom dribbling and long passing at women's football clubs in Bengkulu City. This research was conducted at each training site for women's football clubs in the city of Bengkulu. The population in this study were female football players in the city of Bengkulu, amounting to 60 people. This research is a quantitative descriptive study that uses survey methods and data collection techniques using test and measurement techniques. The sampling technique uses total sampling, where the total population is sampled. The instruments used in this study were danny mielke's slalom dribble and hull passing tests. The data analysis technique used is descriptive statistics in the form of percentages. The results showed that football ability of slalom dribbling in women's football clubs in the city of Bengkulu was declared lacking percentages is $36,67 \%$, and the ability of long passing at women's football clubs in the city of Bengkulu was declared very lacking percentages is $66,67 \%$.
\end{abstract}

Keywords: Ability, Slalom Dribbling, Long Passing, Womens Football. 


\section{PENDAHULUAN}

Olahraga adalah salah satu aktivitas fisik maupun psikis yang berguna untuk menjaga dan meningkatkan kualitas kesehatan seseorang. Olahraga banyak di gemari di masyarakat mulai dari kalangan anak-anak, remaja, dewasa hingga ke lansia. Olahraga juga sebuah sarana untuk menunjang kesehatan jiwa dan raga seseorang.

Menurut UU RI No. 3 tahun 2005 tentang system keolahragaan nasionan Bab 1 pasal 1 ayat 13 sebagai berikut : Olahraga prestasi adalah olahraga yang membina dan mengembangkan olahragawan secara terencana, berjenjang dan berkelanjutan melalui kompetensi untuk mencapai prestasi setinggitingginya dengan dukungan ilmu pengetahuan dan teknologi keolahragaan.

Permainan sepakbola merupakan salah satu cabang olahraga yang digemari dan sangat dikenal oleh masyarakat indonesia. Hal ini dapat dibuktikan dengan banyaknya masyarakat yang memainkannya, baik masyarakat di wilayah perkotaan maupun di wilayah pedesaan. Menurut Robert L. Koger (2005:x) sepak bola adalah permainan yang memungkinkan semua anak bersenang-senang sambil bekerja sama dalam tim. Sedangkan menurut Joe Luxbacher (2004:VII) sepakbola lebih banyak menuntut keterampilan pemain dibandingkan olahraga lain, dalam permainan sepakbola banyak teknik dasar yang harus dikuasai Salah satu teknik dasar yang harus dikuasai oleh seorang pemain sepakbola adalah teknik menggiring bola (dribbling) dan mengoper bola (passing). Dribbling adalah metode menggerakkan bola dari satu titik ke titik lain di lapangan dengan menggunakan kaki menurut Robert $\mathrm{L}$ Koger (2005:51). Sedangkan Passing menurut Danny Mielke (2007:19) adalah seni memindahkan momentum bola dari satu pemain ke pemain lain.

Wanita juga tak mau kalah dalam bermain sepakbola. Namun, sejarah mereka tak bisa lepas dari perjuangan atas upaya untuk mendapat kesetaraan dengan kaum laki-laki. Di Cina pada awalnya sepakbola wanita diperbolehkan berkembang pada masa Dinasti Donghan, tahun 25 Masehi. Para wanita Cina memainkannya sebagai bagian dari hiburan rakyat pada saat itu. Namun, permainan ini lantas dilarang dimainkan oleh wanita pada masa Dinasti Qing (1644). Dinasti itu menganggap, wanita tak pantas memainkan permainan yang didominasi kaum laki-laki. Larangan itu baru dicabut pada tahun 1920 menurut Hendri Firzani (2010).

Salah satu wadah untuk para pesepakbola wanita yaitu ada di Kota Bengkulu. Klub sepak bola wanita merupakan wadah yang bertujuan untuk memperluas wawasan serta peningkatan dan penerapan nilai-nilai pengetahuan dan kemampuan dalam berbagai hal seperti olahraga. Selain itu, klub ini merupakan salah satu wadah untuk mengembangkan potensi-potensi pesepak bola wanita di Kota 
Bengkulu. Klub merupakan salah satu upaya pembinaan yang di selenggarakan di suatu wilayah. Pada kegiatan inilah kemampuan serta keterampilan pesepakbola wanita akan di tingkatkan dengan bentuk-bentuk latihan khusus sesuai olahraga yang di ikuti dan di minati.

\section{Berdasarkan} hasil pengamatan yang di lakukan oleh peneliti, masih belum optimalnya pemain-pemain sepak bola wanita yang ada di Kota Bengkulu dalam melakukan dribbling dan long passing, terlihat ketika mereka bermain sepakbola masih banyaknya kekurangan dalam melakukan dribbling dan long passing yang selalu dapat di patahkan oleh tim lawan. Begitu juga hasil wawancara tidak langsung yang sudah penulis lakukan terhadap pelatih dan masyarakat umum, bahwa tim sepakbola wanita Kota Bengkulu belum dapat menyeimbangi atau bersaing dengan pemain-pemain di luar kota, terlihat saat tim sepakbola Kota Bengkulu mengikuti ajang Piala Pertiwi. Piala Pertiwi merupakan even olahraga rutin yang diselenggarakan oleh PSSI yang melibatkan klub-klub sepakbola wanita dari seluruh asosiasi sepakbola daerah di Indonesia. Berdasarkan latar belakang yang telah di uraikan di atas, peneliti tertarik untuk melakukan penelitian dengan judul "Studi Kemampuan Slalom Dribbling dan Long Passing Pada Klub Sepakbola Wanita di Kota Bengkulu".

\section{METODE}

Penelitian ini adalah jenis penelitian deskriptif kuantitatif. Metode yang di gunakan untuk mengumpulkan data adalah metode survey dengan teknik tes dan pengukuran. Penelitian deskriptif diartikan sebagai suatu penelitian yang berusaha mendeskripsikan suatu fenomena/peristiwa secara sistematis sesuai dengan apa adanya menurut Nyoman Dantes (2012:51).

Menurut Dian Pujianto dan Bayu Insanistyo (2013:71) populasi adalah kelompok besar dimana sampel penelitian diambil. Populasi dalam penelitian ini adalah pemain sepakbola wanita di Kota Bengkulu yang berjumlah 60 orang yang berasal dari klub PS FKIP UNIB, Bengkulu Raya FC, dan Bengkulu Putra FC. Menurut Dian Pujianto dan Bayu Insanistyo (2013:72) sampel merupakan perwakilan dari seluruh populasi yang ada. Teknik pengambilan sampel dalam penelitian ini adalah dengan cara sampel total, yaitu seluruh populasi digunakan sebagai sampel dalam penelitian dikarenakan populasi yang sedikit. Menurut Sugiyono (2016:102) instrumen penelitian adalah suatu alat yang di gunakan untuk mengukur fenomena alam maupun sosial yang diamati. Penelitian ini menggunakan instrumen tes keterampilan sepakbola milik Danny Mielke (2007). 


\section{HASIL DAN PEMBAHASAN}

HASIL

\section{a. Klub PS FKIP UNIB}

Tabel 1. Hasil Tes Kemampuan Slalom

Dribbbling PS FKIP UNIB

\begin{tabular}{|c|c|c|c|c|c|}
\hline $\mathbf{N}$ & $\begin{array}{c}\text { Klasifik } \\
\text { asi } \\
\text { Skor }\end{array}$ & $\begin{array}{c}\text { Ha } \\
\text { sil }\end{array}$ & $\begin{array}{c}\text { Kateg } \\
\text { ori }\end{array}$ & $\begin{array}{c}\text { Juml } \\
\text { ah }\end{array}$ & $\begin{array}{l}\text { Present } \\
\text { ase }\end{array}$ \\
\hline 1 & $\geq 214$ & $\leq 16$ & $\begin{array}{l}\text { Sangat } \\
\text { Baik }\end{array}$ & - & $0 \%$ \\
\hline 2 & $\begin{array}{c}213- \\
205\end{array}$ & $\begin{array}{l}17 \\
- \\
25\end{array}$ & Baik & $\begin{array}{c}14 \\
\text { orang }\end{array}$ & $70 \%$ \\
\hline 3 & $\begin{array}{c}204- \\
196\end{array}$ & $\begin{array}{c}26- \\
34\end{array}$ & Cukup & $\begin{array}{c}3 \\
\text { Oran } \\
\mathrm{g}\end{array}$ & $15 \%$ \\
\hline 4 & $\begin{array}{c}195- \\
187\end{array}$ & $\begin{array}{l}35- \\
43\end{array}$ & $\begin{array}{c}\text { Kuran } \\
\mathrm{g}\end{array}$ & $\begin{array}{c}3 \\
\text { Oran } \\
\mathrm{g}\end{array}$ & $15 \%$ \\
\hline 5 & $\leq 186$ & $\geq 44$ & $\begin{array}{c}\text { Sangat } \\
\text { Kuran } \\
\mathrm{g} \\
\end{array}$ & - & $0 \%$ \\
\hline \multicolumn{4}{|c|}{ Jumlah } & 20 & $100 \%$ \\
\hline
\end{tabular}

Berdasarkan hasil distribusi presentase tes pada tabel 1, maka dapat di simpulkan bahwa kemampuan slalom dribbling pada klub sepakbola wanita PS FKIP UNIB termasuk pada kategori baik dikarenakan rerata 25,37. Hasil penelitian kemampuan slalom dribbling pada klub sepakbola wanita PS FKIP UNIB dengan subjek penelitian 20 orang, menunjukkan bahwa tidak ada pemain yang masuk dalam kategori "sangat baik" (0\%), kategori "baik" 14 orang atau sebesar (70\%), kategori "cukup" 3 orang atau sebesar (15\%), kategori "kurang" 3 orang atau sebesar $(15 \%)$, dan tidak ada pemain yang masuk dalam kategori "sangat kurang" (0\%). Jika di tampilkan dalam bentuk grafik, maka data kemampuan slalom dribbling pada klub PS FKIP UNIB adalah sebagai berikut:

Gambar 1

Grafik Tes Kemampuan Slalom

Dribbling PS FKIP UNIB

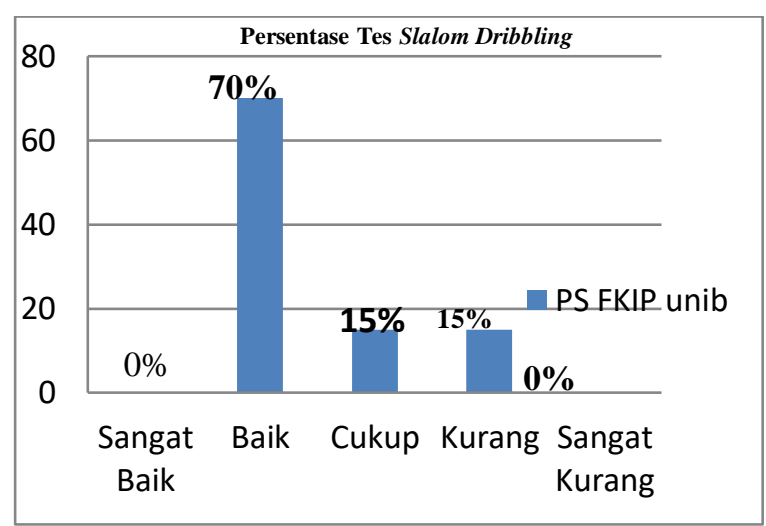

Tabel 2. Hasil Tes Kemampuan Long Passing PS FKIP UNIB

\begin{tabular}{c|c|c|c|c}
$\mathbf{N}$ & Klasifi & Kategori & Jum & Presentase \\
kasi & & lah & \\
\hline 1 & $348-$ & Sangat & 7 & $35 \%$ \\
& 404 & Baik & $\begin{array}{c}\text { Oran } \\
\text { g }\end{array}$ & \\
\hline 2 & $291-$ & Baik & - & $0 \%$ \\
& 347 & & & \\
\hline 3 & $234-$ & Cukup & 5 & $25 \%$ \\
& 290 & & Oran & \\
& & & $\mathrm{g}$ & $10 \%$ \\
\hline 4 & $177-$ & Kurang & 2 & \\
& 233 & & Oran & \\
& & & $\mathrm{g}$ & $30 \%$ \\
\hline 5 & $120-$ & Sangat & 6 & \\
& 176 & Kurang & Oran & \\
\hline \multicolumn{7}{|c|}{ Jumlah } & 20 & $100 \%$
\end{tabular}

Berdasarkan hasil distribusi presentase tes pada tabel 2, maka dapat di simpulkan bahwa kemampuan long passing pada klub sepakbola wanita PS FKIP UNIB termasuk pada kategori cukup dikarenakan rerata 253,50 dari subjek yang berjumlah 20 orang menunjukkan bahwa pemain yang 
masuk pada kategori "sangat baik" 7 orang atau sebesar (35\%), kategori "baik" 0 orang atau sebesar $(0 \%)$, kategori "cukup" 5 orang atau sebesar (25\%), kategori "kurang" 2 orang atau sebesar (10\%), kategori "sangat kurang" 6 orang atau sebesar (30\%). Jika di tampilkan dalam bentuk grafik, maka data kemampuan slalom dribbling pada klub PS FKIP UNIB adalah sebagai berikut:

Gambar 2

Grafik Tes Kemampuan Long

Passing PS FKIP UNIB

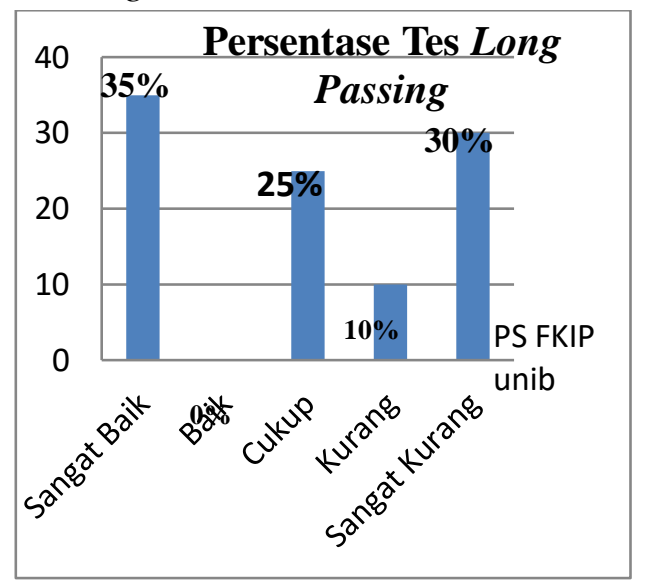

\section{b. Klub Bengkulu Raya FC}

Tabel 3. Hasil Tes Kemampuan

Slalom Dribbling Bengkulu Raya FC

\begin{tabular}{c|c|c|c|c|c}
$\begin{array}{c}\mathbf{N} \\
\mathbf{o}\end{array}$ & $\begin{array}{c}\text { Klasifik } \\
\text { asi Skor }\end{array}$ & $\begin{array}{c}\text { Has } \\
\text { il }\end{array}$ & $\begin{array}{c}\text { Kateg } \\
\text { ori }\end{array}$ & $\begin{array}{c}\text { Juml } \\
\text { ah }\end{array}$ & $\begin{array}{c}\text { Present } \\
\text { ase }\end{array}$ \\
\hline 1 & $\geq 214$ & $\leq 16$ & $\begin{array}{c}\text { Sangat } \\
\text { Baik }\end{array}$ & - & $0 \%$ \\
\hline 2 & $213-$ & 17 & Baik & 4 & $20 \%$ \\
& 205 & - & & Orang & \\
\hline 3 & $204-$ & $26-$ & Cukup & 2 & $10 \%$ \\
& 196 & 34 & & Orang & \\
\hline 4 & $195-$ & $35-$ & Kuran & 8 & $40 \%$ \\
& 187 & 43 & g & Orang & \\
\hline 5 & $\leq 186$ & $\geq 44$ & $\begin{array}{c}\text { Sangat } \\
\text { Kuran }\end{array}$ & $\begin{array}{c}6 \\
\text { Orang }\end{array}$ & $30 \%$ \\
& & & g & & \\
\hline \multicolumn{7}{|c|}{ Jumlah } & & 20 & $100 \%$
\end{tabular}

Berdasarkan hasil distribusi presentase tes pada tabel 3 di atas maka dapat di simpulkan bahwa kemampuan slalom dribbling pada klub sepakbola wanita Bengkulu Raya FC termasuk pada kategori kurang dikarenakan rerata 38,20. Hasil penelitian kemampuan slalom dribbling pada klub sepakbola wanita Bengkulu Raya FC dengan subjek penelitian 20 orang, menunjukkan bahwa tidak ada pemain yang masuk kategori "sangat baik" (0\%), kategori "baik" 4 orang atau sebesar (20\%), kategori "cukup" 2 orang atau sebesar (10\%), kategori "kurang" 8 orang atau sebesar (40\%), kategori "sangat kurang" 6 orang atau sebesar (30\%). Jika di tampilkan dalam bentuk grafik, maka data kemampuan slalom dribbling pada klub Bengkulu Raya FC adalah sebagai berikut:

Gambar 3

Grafik Tes Kemampuan Slalom

Dribbling Bengkulu Raya FC

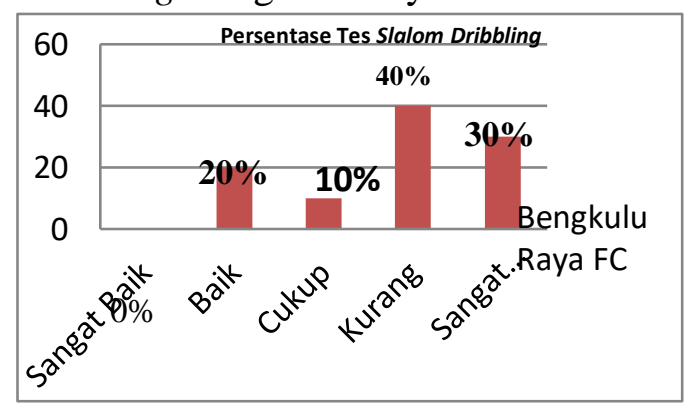

Tabel 4. Hasil Tes Kemampuan Long Passing Bengkulu Raya FC

\begin{tabular}{c|c|c|c|c}
$\mathbf{N}$ & Klasifikas & Kategor & Jumla & Presentas \\
$\mathbf{0}$ & i Skor & $\mathbf{i}$ & $\mathbf{h}$ & $\mathbf{e}$ \\
\hline 1 & $348-404$ & $\begin{array}{c}\text { Sangat } \\
\text { Baik }\end{array}$ & - & $0 \%$ \\
& & & \\
\hline
\end{tabular}




\begin{tabular}{c|c|c|c|c}
\hline 2 & $291-347$ & Baik & $\begin{array}{c}1 \\
\text { Orang }\end{array}$ & $5 \%$ \\
\hline 3 & $234-290$ & Cukup & $\begin{array}{c}1 \\
\text { Orang }\end{array}$ & $5 \%$ \\
\hline 4 & $177-233$ & Kurang & $\begin{array}{c}1 \\
\text { Orang }\end{array}$ & $5 \%$ \\
\hline 5 & $120-176$ & $\begin{array}{c}\text { Sangat } \\
\text { Kurang }\end{array}$ & $\begin{array}{c}17 \\
\text { Orang }\end{array}$ & $85 \%$ \\
\hline \multicolumn{3}{|c|}{ Jumlah } & 20 & $100 \%$
\end{tabular}

Berdasarkan hasil distribusi presentase tes pada tabel 4 di atas maka dapat di simpulkan bahwa kemampuan long passsing pada klub sepakbola wanita Bengkulu Raya FC termasuk pada kategori sangat kurang dikarenakan rerata 125,50 dari subjek yang berjumlah 20 orang menunjukkan bahwa tidak ada pemain yang masuk pada kategori "sangat baik" (0\%), kategori "baik" 1 orang atau sebesar (5\%), kategori "cukup" 1 orang atau sebesar (5\%), kategori "kurang" 1 orang atau sebesar (5\%), kategori "sangat kurang" 17 orang atau sebesar (85\%). Jika di tampilkan dalam bentuk grafik, maka data kemampuan slalom dribbling pada klub Bengkulu Raya FC adalah sebagai berikut:

\section{Gambar 4}

\section{Grafik Tes Kemampuan Long}

Passing Bengkulu Raya FC

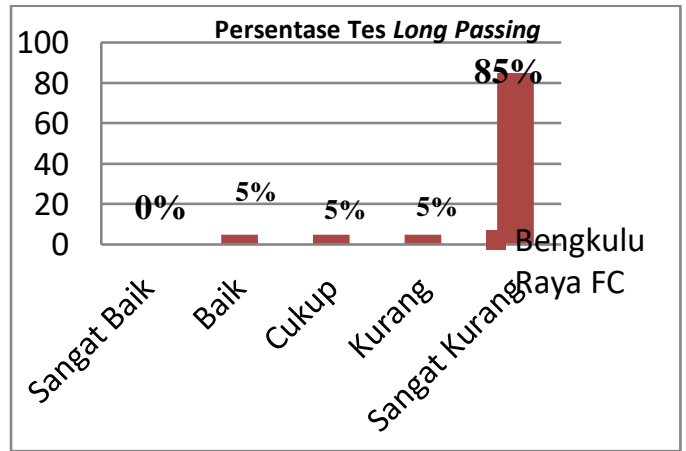

\section{c. Klub Bengkulu Putra. FC}

Tabel 5. Hasil Tes Kemampuan

Slalom Dribbling Bengkulu Putra.

FC

\begin{tabular}{|c|c|c|c|c|c|}
\hline $\begin{array}{l}\mathbf{N} \\
\mathbf{0}\end{array}$ & $\begin{array}{l}\text { Klasifik } \\
\text { asi Skor }\end{array}$ & $\begin{array}{c}\text { Has } \\
\text { il }\end{array}$ & $\begin{array}{c}\text { Kateg } \\
\text { ori }\end{array}$ & $\begin{array}{c}\text { Juml } \\
\text { ah }\end{array}$ & $\begin{array}{c}\text { Present } \\
\text { ase }\end{array}$ \\
\hline 1 & $\geq 214$ & $\leq 16$ & $\begin{array}{c}\text { Sangat } \\
\text { Baik }\end{array}$ & - & $0 \%$ \\
\hline 2 & $\begin{array}{c}213- \\
205\end{array}$ & $\begin{array}{l}17- \\
25\end{array}$ & Baik & $\begin{array}{c}4 \\
\text { orang }\end{array}$ & $20 \%$ \\
\hline 3 & $\begin{array}{c}204- \\
196\end{array}$ & $\begin{array}{l}26- \\
34\end{array}$ & Cukup & - & $0 \%$ \\
\hline 4 & $\begin{array}{c}195- \\
187\end{array}$ & $\begin{array}{c}35- \\
43\end{array}$ & $\begin{array}{c}\text { Kuran } \\
\mathrm{g}\end{array}$ & $\begin{array}{c}11 \\
\text { Orang }\end{array}$ & $55 \%$ \\
\hline 5 & $\leq 186$ & $\geq 44$ & $\begin{array}{c}\text { Sangat } \\
\text { Kuran } \\
\text { g }\end{array}$ & $\begin{array}{c}5 \\
\text { Orang } \\
\\
20\end{array}$ & $100 \%$ \\
\hline
\end{tabular}

Berdasarkan hasil distribusi presentase tes pada tabel 5 di atas maka dapat di simpulkan bahwa kemampuan slalom dribbling pada klub sepakbola wanita Bengkulu Putra FC termasuk pada kategori kurang dikarenakan rerata 38,36. Hasil penelitian kemampuan slalom dribbling pada klub sepakbola wanita Bengkulu Putra FC dengan subjek penelitian 20 orang, menunjukkan bahwa tidak ada pemain yang masuk kategori "sangat baik" (0\%), kategori "baik" 4 orang atau sebesar (20\%), kategori "cukup" 0 orang atau sebesar $(0 \%)$, kategori "kurang" 11 orang atau sebesar (55\%), kategori "sangat kurang" 5 orang atau sebesar (25\%). Jika di tampilkan dalam bentuk grafik, maka data kemampuan slalom dribbling pada klub Bengkulu Putra FC adalah sebagai berikut: 
Gambar 5

Grafik Tes Kemampuan Slalom

Dribbling Bengkulu Putra FC

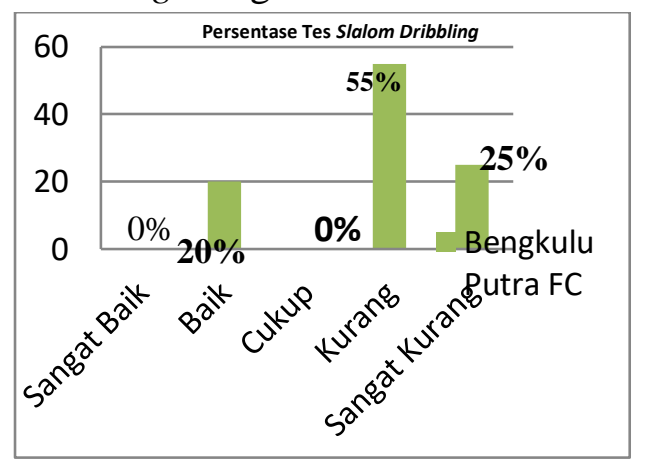

Tabel 6. Hasil Tes Kemampuan Long

Passing Bengkulu Putra. FC

\begin{tabular}{|c|c|c|c|c|}
\hline $\begin{array}{l}\mathbf{N} \\
\mathbf{0}\end{array}$ & $\begin{array}{c}\text { Klasifikas } \\
\text { i Skor }\end{array}$ & $\begin{array}{c}\text { Kategor } \\
\text { i }\end{array}$ & $\begin{array}{c}\text { Jumla } \\
\mathbf{h}\end{array}$ & $\begin{array}{c}\text { Presentas } \\
\text { e }\end{array}$ \\
\hline 1 & $348-404$ & $\begin{array}{c}\text { Sangat } \\
\text { Baik }\end{array}$ & - & - \\
\hline 2 & $291-347$ & Baik & $\begin{array}{c}1 \\
\text { Orang }\end{array}$ & $5 \%$ \\
\hline 3 & $234-290$ & Cukup & $\begin{array}{c}1 \\
\text { Orang }\end{array}$ & $5 \%$ \\
\hline 4 & $177-233$ & Kurang & $\begin{array}{c}1 \\
\text { Orang }\end{array}$ & $5 \%$ \\
\hline 5 & $120-176$ & $\begin{array}{l}\text { Sangat } \\
\text { Kurang }\end{array}$ & $\begin{array}{c}17 \\
\text { Orang }\end{array}$ & $85 \%$ \\
\hline \multicolumn{3}{|c|}{ Jumlah } & 20 & $100 \%$ \\
\hline
\end{tabular}

Berdasarkan hasil distribusi presentase tes pada tabel 6 di atas maka dapat di simpulkan bahwa kemampuan long passing pada klub sepakbola wanita Bengkulu Putra FC termasuk pada kategori sangat kurang dikarenakan rerata 115,50 dari subjek yang berjumlah 20 orang menunjukkan bahwa tidak ada pemain yang masuk pada kategori "sangat baik" (0\%), kategori "baik" 1 orang atau sebesar (5\%), kategori "cukup" 1 orang atau sebesar (5\%), kategori "kurang" 1 orang atau sebesar (5\%), kategori "sangat kurang" 17 orang atau sebesar (85\%). Jika di tampilkan dalam bentuk grafik, maka data kemampuan slalom dribbling pada klub Bengkulu Putra FC adalah sebagai berikut:

Gambar 6

Grafik Tes Kemampuan Long Passing Bengkulu Putra FC

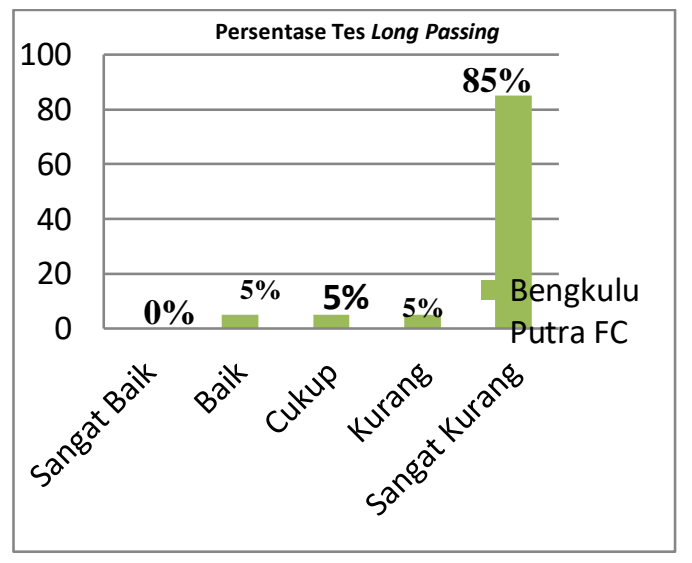

\section{PEMBAHASAN}

Dari deskripsi hasil penelitian yang dilakukan tentang "Studi Kemampuan Slalom Dribbling dan Long Passing Pada Klub Sepakbola Wanita di Kota Bengkulu" untuk tes Slalom Dribbling adalah kurang dengan pertimbangan frekuensi terbanyak adalah 22 atau 36,67\%. Tingkat kemampuan slalom dribbling yang berkategori sangat baik sebesar $0 \%$, baik sebesar $35 \%$, cukup sebesar $10 \%$, kurang sebesar $36,67 \%$, dan sangat kurang sebesar $18,33 \%$.

Dribbling yang sering digunakan oleh pemain sepakbola adalah dribbling menggunakan kaki bagian dalam, hal ini memungkinkan pemain untuk menggunakan sebagian besar permukaan kaki sehingga kontrol terhadap bola akan semakin besar dan menjaga bola 
tetap di daerah terlindung di antara kedua kaki. Menurut Justinus Lhaksana (2011:33) teknik dribbling merupakan keterampilan penting dan mutlak yang harus dikuasai oleh setap pemain. Dari data yang telah diperoleh, presentase terbaik untuk tes slalom dribbling didapat oleh pemain klub PS FKIP UNIB dengan presentase baik sebesar $65 \%$. Berdasarkan pengamatan peneliti, pemain-pemain dengan kategori baik ini memiliki kemampuan yang berbeda dari pemain lainnya. Tes slalom dribbling dilakukan secara baik dalam hal teknik maupun kecepatan dan kelincahan. Pemainpemain yang mendapatkan hasil terbaik ini melakukan tes slalom dribbling dengan menggunakan teknik ketiga sisi kaki, yaitu membawa bola dengan menggunakan kaki bagian dalam, kaki bagian luar dan sisi kura-kura kaki. Hal ini tentunya berpengaruh pada hasil tes. Teknik ini apabila dilakukan secara baik dan benar akan mendapatkan hasil yang baik dan cepat dibandingkan dengan pemain yang hanya menggunakan teknik salah satu sisi kaki saja. Pemain pemula akan memilih melakukan dribbling dengan menggunakan sisi bagian dalam saja. Ketika kamu semakin matang sebagai pemain dan merasa percaya diri terhadap kemampuan dribbling, cobalah mengontrol bola menggunakan sisi kura-kura kaki dan sisi kaki bagian luar menurut Danny Mielke (2007:1).

Sedangkan kemampuan long passing pada klub sepakbola wanita di Kota Bengkulu adalah sangat kurang dengan pertimbangan frekuensi terbanyak adalah 40 atau $66,67 \%$. Tingkat kemampuan long passing yang berkategori sangat baik $11,67 \%$, baik sebesar $3,33 \%$, cukup sebesar $11,67 \%$, kurang $6,66 \%$, dan sangat kurang $66,67 \%$. Long passing dilakukan dengan menggunakan punggung kaki. Tendangan long passing sering dilakukan pada saat terjadi pelanggaran di lapangan tengah, tendangan gawang dan tendangan sudut. Tendangan long passing dapat dilakukan dengan baik apabila sikap awal yang dilakukan kedua kaki dan arah tubuh berada pada posisi yang benar. Menurut Justinus Lhaksana (2011:30) passing merupakan salah satu teknik dasar yang sangat dibutuhkan oleh setiap pemain.

Klub PS FKIP UNIB unggul pada tes long passing dengan presentase sebesar 35\% jika dibandingkan dengan klub lain yang hanya mampu mendapatkan presentase 5\% untuk kategori baik. $\mathrm{Hal}$ ini tentu menunjukkan kemampuan pemain PS FKIP UNIB lebih unggul jika dibandingkan dengan klub lainnya. Sesuai dengan pengamatan peneliti, bahwa pada tes long passing yang dilakukan oleh pemain klub Bengkulu Raya dan Bengkulu Putra FC masih banyak melakukan kesalah pada saat menendang bola. Pemain Bengkulu Raya dan Bengkulu Putra FC banyak menggunakan kaki bagian dalam untuk menendang bola operan panjang (the long pass). Pemain ini juga cenderung tidak seimbang 
ketika melakukan tendangan, jarak antara kaki dan bola juga terlalu jauh ketika melakukan tendangan. Sedangkan untuk pemain klub PS FKIP UNIB lebih banyak pemain yang menggunakan sisi atas kaki/punggung kaki, hal ini adalah salah satu yang mempengaruhi tendangan long pass baik dan terarah. Sikap pemain PS FKIP UNIB juga lebih baik dari pada klub lainnya, kaki pemain yang bertumpu tepat di samping bola, lengan direntangkan untuk keseimbangan, dan tendangan yang tepat pada sisi kaki bagian depan. Sisi kaki bagian dalam digunakan untuk operan pendek dan hanya berkekuatan terbatas, gunakanlah sisi atas kaki untuk melakukan tendangan jarak jauh, ini merupakan keterampilan yang lebih sulit dan harus tepat, (WH Smith, 1981:24). Penelitian ini sesuai dengan latar belakang permasalahan yang terjadi melihat data yang diperoleh oleh peneliti bahwa selama ini pemain sepakbola wanita di Kota Bengkulu masih kurang mampu menguasai permainan saat pertandingan, permainan juga sering di dominasi oleh short pass sehingga masih banyak bola yang terpotong oleh lawan, hal ini dikarenakan kurangnya kemampuan dribbling dan long passing pemain sepakbola wanita di Kota Bengkulu.

PENUTUP

\section{SIMPULAN}

Berdasarkan hasil penelitian
dan pembahasan yang telah
diuraikan dapat disimpulkan bahwa
Kemampuan slalom dribbling pada pemain sepakbola wanita di Kota Bengkulu adalah kurang dengan presentase sebesar $36,67 \% \quad(22$ orang). Sedangkan kemampuan long passing pada pemain sepakbola wanita di Kota Bengkulu adalah sangat kurang dengan presentase sebesar $66,67 \%$ (40 orang).

\section{DAFTAR PUSTAKA}

Dantes, Nyoman. 2012. Metode Penelitian. Yogyakarta: Andi Yogyakarta.

Dian Pujianto \& Bayu Insanistyo. 2013. Dasar-Dasar Penelitian Pendidikan Jasmani. Bengkulu : Fkip Press Universitas Bengkulu 2017.

Firzani, Hendri. 2010. Segalanya Tentang Sepak Bola. Jakarta:Penerbit Erlangga.

Koger, Robert L. 2005. Latihan Dasar Andal Sepak Bola Remaja. Klaten: SMK/Seri Olahraga.

Leo, Arwin, dan Syafrial. 2017. "Profil Kondisi Fisik Pemain Sepak Bola SMA Negeri 1 Kaur" Jurnal Kinestetik, Vol. 1 (1).

Lhaksana, Justinus. 2011. Taktik Dan Strategi Futsal Modern. Jakarta: Be Champion.

Luxbacher Joseps. 2004. "SEPAKBOLA".Jakarta : PT Rajagrafindo Persada.

Mielke, Danny. 2007. Dasar-Dasar Sepak Bola. Australia : Penerbit Pakar Raya. 
Smitfh, H. W. 1981. Sepak Bola:

Keterampilan, Taktik, Fakta.

Jakarta-Indonesia.

Sugiyono. 2016. Metode Penelitian

Kuantitatif, Kualitatif, dan

$R \& D$. Bandung: Alfa Beta. 